\title{
PERUBAHAN FORCE NIKEL TITANIUM CLOSED COIL SPRING DAN ELASTIC
} CHAIN TERHADAP PERUBAHAN TEMPERATUR

\author{
Zulfan Muttaqin, Riris Aprila, Reka, Ananda Aprilia, Chandra Susanto \\ *Fakultas Kedokteran Gigi, Universitas Prima Indonesia \\ e-mail: mottakeane@gmail.com
}

\section{KEYWORDS}

orthodontic appliances, force, nickel titanium closed coil spring, elastic chain, temperature.

\section{PENDAHULUAN}

Wajah merupakan salah satu bagian yang tidak luput dari penampilan seseorang. Bentuk atau estetika dari wajah biasanya dinilai dari susunan gigi rahang atas dan gigi rahang bawah yang memiliki hubungan harmonis terutama pada gigi anterior. Susunan gigi yang tidak normal disebut juga maloklusi. Untuk mengatasi maloklusi dapat dilakukan perawatan ortodonti untuk mencapai keseimbangan antar oklusal gigi geligi sehingga dapat menunjang estetika wajah yang lebih menarik. ${ }^{1}$ Ortodonsia adalah ilmu yang mempelajari pertumbuhan dan perkembangan gigi dan jaringan sekitarnya dari janin sampai dewasa dengan tujuan mencegah dan memperbaiki keadaan gigi yang letaknya tidak baik untuk mencapai hubungan fungsional serta anatomis yang normal. ${ }^{2}$ Ortodonti cekat adalah salah satu alat yang digunakan dalam kedokteran gigi berfungsi untuk merapikan gigi yang tidak beraturan. Biasanya melibatkan penggunaan bracket yang dipasang secara permanen pada gigi. Alat ini memiliki bentuk yang rumit dan mempunyai kemampuan perawatan yang lebih kompleks. ${ }^{3}$ Komponen ortodonti cekat dikategorikan menjadi 2 komponen yaitu 
pasif dan aktif, komponen pasif berfungsi untuk komponen aktif sedangkan komponen aktif berfungsi untuk menggerakkan gigi. Pergerakan ortodonti adalah proses dari respon biologis tulang alveolar terhadap tekanan yang mengakibatkan resorpsi tulang dan tegangan yang mengakibatkan aposisi pada tulang. Prinsip dasar dalam ortodonti adalah "Bone Traces Tooth Movement", dimana pergerakan gigi ortodonti dengan pembentukan kembali tulang harus sama dengan rasio 1:1. ${ }^{4}$ Pengguna alat ortodonti cekat juga akan mengalami peningkatan laju aliran saliva. Ortodonti cekat akan menyebabkan perubahan lingkungan rongga mulut, alat ortodonti cekat akan mengakibatkan akumulasi plak yang dapat meningkatkan jumlah dari mikroba dan perubahan komposisi dari microbial mikroba yang ada dalam plak diantaranya adalah Streptococcus mutans dan Lactobacillus. ${ }^{5}$ Perubahan lingkungan rongga mulut yang lain yaitu perubahan kapasitas buffer, keasaman $\mathrm{pH}$, perubahan temperatur dan laju aliran saliva. ${ }^{5}$ NiTi open dan closed coil spring mempunyai sifat elastic yang dapat kembali ke bentuk semula berfungsi untuk membuka dan menutup ruang (space closure) pada gigi dan membuat pergerakan mesialisasi molar, terutama pada shape memory alloys closed coil spring telah menjadi alat intradental yang berguna untuk menutup ruang dalam berbagai terapi ortodonti, tekanan yang sangat efisien dan stabil, dan beragam kekuatan seperti (extra light 50 gram), (light 100 gram), (medium 1500 gram), dan (heavy 200 gram) dan untuk NiTi closed coil spring tersedia manual dan pabrikan. ${ }^{7}$ NiTi closed coil paling banyak di pakai untuk perawatan ortodonti dibanding coil lainnya karena sifatnya yang stabil dan mempunyai sifat shape memory yang baik, selain NiTi closed coil spring masih banyak material yang berfungsi untuk menutup ruangan seperti stainless steel coil sping, elastic chain dan masih banyak lagi. Sama seperti NiTi closed coil spring yang menutup ruangan pada ortodonti. ${ }^{8}$ Elastic chain adalah salah satu elastic yang tersedia dalam bentuk rantai panjang dengan lubang yang saling terhubung (interkoneksi). Elastic chain biasanya terbuat dari 2 jenis bahan: alami atau sintetis lateks, menjadi semakin populer sifat mekanik dan elastis yang lebih baik, serta fakta bahwa semakin banyak orang alergi terhadap lateks alami. ${ }^{9}$ Fungsi dari elastic chain tersebut menyerupai NiTi closed coil spring yang berfungsi untuk menggerakkan gigi dan menutup ruang (space closure), adapun tingkat kekuatan dari elastic chain tersebut dibagi menjadi 3 berdasarkan jarak antara rantainya yaitu tipe panjang, tipe pendek dan tipe bersambung. Faktor-faktor terkait lingkungan intraoral seperti $\mathrm{pH}$ saliva, enzim, diet, aksi fisik menyikat gigi, variasi suhu dapat merubah kerja ortodonti. ${ }^{9}$ Temperatur yang berbedabeda pada makanan bisa saja merubah tekanan pada material-material tersebut, apalagi yang mengkonsumsi makanan dan 
minuman yang suhu ekstrim di atas maupun di bawah suhu normal. ${ }^{10}$ Adapun temperatur pada es krim dan es batu pada temperatur $5^{\circ} \mathrm{C}$ dan untuk kopi dan sop pada $60^{\circ} \mathrm{C}$, pengguna ortodonti terutama yang menggunakan NiTi closed coil spring dan elastic chain tentu akan merasakan makanan dalam temperatur yang berbeda untuk diet mereka. ${ }^{9}$ Pada daerah yang bersuhu panas tentu mereka menikmati makanan dan minuman yang bersuhu dingin untuk mereka konsumsi sama seperti daerah panas daerah dingin juga pasti akan mengkonsumsi makanan yang meng-hangatkan tubuh mereka dan untuk yang penikmat kopi mereka akan meminum kopi dalam kondisi suhu yang panas maupun dingin karena sudah menjadi kesukaan penikmat kopi.

\section{METODE}

Jenis penelitian ini merupakan penelitian eksperimental, yaitu suatu metode penelitian yang dilakukan dengan melibatkan 3 kelompok perlakuan dan diukur sebelum diberikan perlakuan Penelitian ini dilakukan di laboratorium Universitas Prima Indonesia tepatnya di Fakultas Kedokteran Universitas Prima Indonesia pada bulan Desember 2019. Penelitian menggunakan Elastic chain tipe short berwarna putih dan NiTi closed coil spring tipe length sebagai sampel, dengan besar sampel yang digunakan berdasarkan rumus adalah 6 dalam setiap kelompok perlakuan. Sampel dikaitkan dalam 1 papan akrilik yang memiliki tinggi: $6,5 \mathrm{~cm}$, lebar
$12 \mathrm{~cm}$ dan jarak antar penyangga yaitu $2 \mathrm{~cm}$ dan paku penyangga dengan ukuran 1 inch seperti pada gambar 1. Peneliti menggunakan sampel sebanyak 18 sampel untuk 1 kali perlakuan. Jadi, 1 papan akrilik terdiri dari 6 sampel. Pada penelitian digunakan 3 media perendaman dengan suhu yang berbeda yakni $5^{\circ} \mathrm{C}, 37^{\circ} \mathrm{C}$ dan $60^{\circ} \mathrm{C}$. Kemudian terdapat 5 selang waktu 0 jam, 24 jam, 72 jam, 168 jam dan 240 jam. Dimana kelompok 1 yaitu NiTi closed coil spring dan elastic chain direndam dalam suhu $5^{\circ} \mathrm{C}$ sebanyak 6 sampel dalam kurun waktu 0 jam, 24 jam, 72 jam, 168 jam dan 240 jam, kelompok 2 yaitu NiTi closed coil spring dan elastic chain yang direndam dalam suhu $37^{\circ} \mathrm{C}$ sebanyak 6 sampel dalam kurun waktu 0 jam, 24 jam, 72 jam, 168 jam dan 240 jam dan kelompok 3 yaitu NiTi closed coil spring dan elastic chain direndam dalam suhu $60^{\circ} \mathrm{C}$ sebanyak 6 sampel dalam kurun waktu 0 jam, 24 jam, 72 jam, 168 jam dan 240 jam. Jadi, total semua sampel yang akan diteliti adalah NiTi closed coil spring 18 dan elastic chain 18 dan total dari semua sampel menjadi 36 sampel. Adapun alat yang digunakan dalam penelitian adalah alat ukur force: NK-500N Dial Mechanical pull Gauge, inkubator, box tempat perendaman papan beserta aksesoris ortodonti, needle holder, papan akrilik sebanyak 6 papan dan paku kecil sebesar 1 inci.

Prosedur penelitian ini diawali dengan persiapan sampel elastic chain putih dengan tipe short dan panjang $15 \mathrm{~mm}$ dan NiTi closed coil spring dengan tipe length dengan 
panjang $9 \mathrm{~mm}$ selanjutnya dilakukan pengelompokan pada masing-masing sampel kemudian dilakukan peregangan pada elastic chain dan NiTi closed coil spring diantara 2 buah paku statis pada papan akrilik dengan jarak yakni dari panjang awal NiTi closed coil spring $9 \mathrm{~mm}$ menjadi $25 \mathrm{~mm}$.

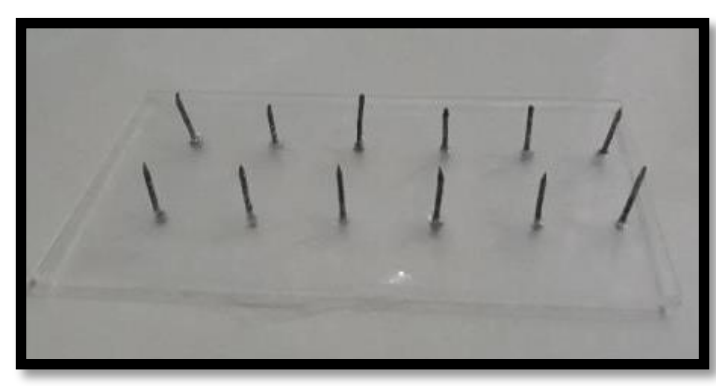

Gambar 1. Papan akrilik dan paku

Kemudian saliva buatan disiapkan dalam wadah sebagai bahan perendaman, pastikan seluruh sampel pada papan akrilik tersebut dimasukkan ke dalam media perendaman yang berisi saliva buatan sesuai dengan suhu yang telah ditentukan lalu tutup wadah dan pastikan sampel harus terendam sepenuhnya di dalam larutan saliva buatan tersebut. Lalu sampel dimasukkan ke dalam inkubator dan dilakukan kontrol suhu pada setiap wadah yang telah diatur dalam masing-masing suhu. Pengukuran force dilakukan dengan alat force: NK-500N Dial Mechanical pull Gauge dan hasil didapatkan dengan menggunakan needle holder untuk melepas satu sisi elastic chain dan NiTi closed coil spring, kemudian ukur force dari elastic chain dan NiTi closed coil spring menggunakan alat ukur force gauge pada satu sisi yang telah dilepas sebelumnya, kemudian ambil nilai rataratanya pada 0 jam, 24 jam, 72 jam, 168 jam,
240 jam. Uji Kruskal Wallis dilakukan untuk mengetahui pengaruh perbedaan force terhadap NiTi closed coil spring dan elastic chain

\section{HASIL}

Hasil uji Kruskal Wallis $(\alpha=0,05)$ menunjukkan ada perbedaan force NiTi closed coil spring yang direndam dalam suhu $5^{\circ} \mathrm{C}, 37^{\circ} \mathrm{C}$ dan $60^{\circ} \mathrm{C}$ yang dilihat pada jangka waktu 24 jam, 72 jam, 168 jam dan 240 jam. Dari hasil ini terlihat nilai force NiTi closed coil spring yang direndam dalam suhu $37^{\circ} \mathrm{C}$ 240 jam lebih kecil dibandingkan dengan nilai force NiTi closed coil spring yang direndam dalam suhu $5^{\circ} \mathrm{C}$ dan suhu $60^{\circ} \mathrm{C}$. Maka demikian, dapat dinyatakan bahwa terdapat perbedaan force NiTi closed coil spring dan elastic chain sebelum dan sesudah diaplikasikan terhadap perubahan temperatur.

Tabel 1. Hasil uji kruskal wallis $(\alpha=0,05)$ force $\mathrm{NiTi}$ closed coil spring

\begin{tabular}{cccc}
\hline Waktu & Suhu & Mean Rank & p value \\
\hline \multirow{3}{*}{24 jam } & $5^{\circ}$ & 9,50 & \\
& $37^{\circ}$ & 9,50 & 1,000 \\
& $60^{\circ}$ & 9,50 & \\
72 jam & $5^{\circ}$ & 9,50 & \\
& $37^{\circ}$ & 3,50 & $0,000^{*}$ \\
& $60^{\circ}$ & 15,50 & \\
\hline \multirow{4}{*}{168 jam } & $5^{\circ}$ & 9,50 & \\
& $37^{\circ}$ & 3,50 & $0,000^{*}$ \\
\hline \multirow{2}{*}{$240 \mathrm{jam}$} & $60^{\circ}$ & 15,50 & \\
& $5^{\circ}$ & 12,50 & \\
& $37^{\circ}$ & 3,50 & $0,000^{*}$ \\
\hline
\end{tabular}

* = Signifikan

Hasil uji Kruskal Wallis $(\alpha=0,05)$ menunjukkan ada perbedaan force elastic chain yang direndam dalam suhu $5^{\circ} \mathrm{C}, 37^{\circ} \mathrm{C}$ dan $60^{\circ} \mathrm{C}$ yang dilihat pada jangka waktu 24 
jam, 72 jam, 168 jam dan 240 jam. Dari hasil ini terlihat nilai force elastic chain yang direndam dalam suhu $5^{\circ} \mathrm{C} 240$ jam lebih kecil dibandingkan dengan nilai force elastic chain yang direndam dalam suhu $37^{\circ} \mathrm{C}$ dan suhu $60^{\circ} \mathrm{C}$.

Tabel 2 .Hasil uji kruskal wallis $(\alpha=0,05)$ force elastic chain

\begin{tabular}{|c|c|c|c|}
\hline Waktu & Suhu & Mean Rank & $p$ value \\
\hline \multirow{3}{*}{24 jam } & $5^{\circ}$ & 9,50 & \multirow{3}{*}{$0,000^{*}$} \\
\hline & $37^{\circ}$ & 9,50 & \\
\hline & $60^{\circ}$ & 9,50 & \\
\hline \multirow{3}{*}{72 jam } & $5^{\circ}$ & 6,50 & \multirow{3}{*}{$0,000^{*}$} \\
\hline & $37^{\circ}$ & 6,50 & \\
\hline & $60^{\circ}$ & 15,50 & \\
\hline \multirow{3}{*}{168 jam } & $5^{\circ}$ & 3,50 & \multirow{3}{*}{$0,000^{*}$} \\
\hline & $37^{\circ}$ & 9,50 & \\
\hline & $60^{\circ}$ & 15,50 & \\
\hline \multirow{3}{*}{$240 \mathrm{jam}$} & $5^{\circ}$ & 3,50 & \multirow{3}{*}{$0,000^{*}$} \\
\hline & $37^{\circ}$ & 12,50 & \\
\hline & $60^{\circ}$ & 12,50 & \\
\hline
\end{tabular}

\section{PEMBAHASAN}

Perawatan ortodonti merupakan perawatan dengan menggunakan piranti ortodonti yang memiliki tujuan untuk memperbaiki susunan dari gigi-geligi dan lengkung gigi yang tidak normal, sehingga tercapainya oklusi yang normal. ${ }^{11}$ Elastic chain dan NiTi closed coil spring merupakan suatu piranti ortodonti yang menunjukkan adanya penurunan kekuatan, tekanan ataupun gaya seiring dengan bertambahnya waktu dan tingginya temperatur dari saliva buatan. Semakin lama waktu perendaman dan semakin tinggi temperatur dari saliva buatan, maka semakin rendah kekuatan atau force yang dihasilkan oleh elastic chain dan NiTi closed coil spring. ${ }^{12}$ Berdasarkan hasil penelitian menunjukkan bahwa force awal yang dari elastic chain adalah sebesar 1,5 $\mathrm{N}$ dengan temperatur yang berbeda-beda yaitu $5^{\circ} \mathrm{C}$, $37^{\circ} \mathrm{C}$ dan $60^{\circ} \mathrm{C}$. Rata-rata force akhir yang dihasilkan oleh elastic chain dalam jangka waktu 240 jam kemudian pada kelompok temperatur $5^{\circ} \mathrm{C}, 37^{\circ} \mathrm{C}$ dan $60^{\circ} \mathrm{C}$ berubah menjadi $1,00 \pm 0,0081 ; 0,24 \pm 0,0081$ dan $0,22 \pm 0,0150$ N. Sedangkan pada NiTi closed coil spring, rata-rata force awal yang dihasilkan pada temperatur $5^{\circ} \mathrm{C}, 37^{\circ} \mathrm{C}$, dan $60^{\circ} \mathrm{C}$ adalah sebesar $1 \mathrm{~N}$. Kemudian, pada jangka waktu 240 jam kemudian, force yang dihasilkan oleh NiTi closed coil spring berubah menjadi $0,53 \pm 0,0337 ; 0,49 \pm 0,133$ dan $0,49 \pm 0,0098$ N. Hasil penelitian ini menunjukkan bahwa adanya perubahan force, baik itu force dari elastic chain maupun force NiTi closed coil spring, sebelum dilakukan perendaman (0 jam) sampai dengan sesudah perendaman (240 jam) terhadap temperatur saliva buatan yang berbeda-beda. Hasil penelitian ini sejalan dengan penelitian yang dilakukan oleh Weissheimer dkk (2013) menyatakan bahwa seluruh kelompok perlakuan menunjukkan adanya penurunan kekuatan dalam periode waktu tertentu yaitu sebesar 59-69\%. Pada penelitian ini, force akhir yang dihasilkan oleh NiTi closed coil spring lebih kecil dibandingkan dengan force akhir yang dihasilkan oleh elastic chain. Keadaan ini dapat diartikan bahwa force dari elastic chain lebih stabil daripada force NiTi closed coil spring. Pernyataan tersebut sejalan dengan penelitian yang dilakukan oleh Sulaiman dkk (2016) yang menyatakan 
bahwa elastic chain memiliki gaya yang lebih stabil dibandingkan dengan NiTi closed coil spring. Elastic chain merupakan kelompok polimer amorf yang terbentuk dari bahan poliuretan dengan karakteristik karet dan plastik $^{12}$. Piranti ortodonti ini telah banyak digunakan dalam berbagai situasi dikarenakan kestabilannya. ${ }^{13}$ Kestabilan dari force elastic chain tersebut dapat disebabkan oleh adanya proses penarikan dari ion $\mathrm{H}^{+}$ yang bermuatan positif. Penarikan ion $\mathrm{H}^{+}$ yang bermuatan positif tersebut terjadi dari molekul air yang berpindah ke dalam molekul yang polimer. Dampaknya, rantai dari elastic chain menjadi lebih besar dibandingkan dengan rantai elastic chain sebelumnya. ${ }^{14}$ Akibatnya, struktur antar polimer akan menjadi lebih jauh. Masuknya molekul-molekul air tersebut dapat mengakibatkan force dari elastic chain menjadi lebih kecil. ${ }^{14}$ Hasil penelitian ini sejalan dengan penelitian yang dilakukan oleh Pires dkk (2011) yang menemukan bahwa penurunan tekanan yang terjadi pada elastic chain lebih tinggi dibandingkan dengan force NiTi closed coil spring. Syaukani (2011) dalam penelitiannya menyatakan bahwa penurunan gaya dari elastic chain dengan berbagai merk paling besar terjadi pada 24 jam setelah dilakukan perlakuan, untuk selanjutnya gaya akan menurun sedikit demi sedikit secara konstan. Namun, pernyataan yang dikemukakan oleh Syaukani (2011) tersebut berbeda dengan hasil penelitian ini yang menemukan bahwa penurunan force terbesar, baik itu pada elastic chain maupun NiTi closed coil spring terjadi pada 72 jam setelah dilakukan perendaman dalam berbagai temperatur saliva buatan yang berbeda. Hasil penelitian ini juga berbeda dengan penelitian yang dilakukan oleh Braga dkk (2019) yang menyatakan bahwa degradasi penurunan kekuatan dari elastic chain berada diantara rentang periode waktu 7 hari sampai dengan 14 hari setelah dilakukan perendaman dalam air panas, green tea dan kopi dengan masingmasing suhu sebesar $70 \pm 1^{\circ} \mathrm{C}$. Pengaruh saliva buatan terhadap penurunan force pada elastic chain maupun NiTi closed coil spring lebih disebabkan oleh temperatur dibandingkan dengan kandungan mineral yang terdapat dalam saliva buatan tersebut. Berdasarkan hasil uji statistik Kruskal Wallis $(\alpha=0,05)$ menunjukkan bahwa terdapat perubahan force dari elastic chain dan NiTi closed coil spring sesudah diaplikasikan terhadap perubahan temperatur yaitu $5^{\circ} \mathrm{C}$, $37^{\circ} \mathrm{C}$ dan $60^{\circ} \mathrm{C}$ yang dilihat pada jangka waktu 0 jam, 24 jam, 72 jam, 168 jam dan 240 jam. Dari hasil penelitian ini dapat diartikan bahwa adanya pengaruh temperatur dari saliva buatan terhadap perubahaan force pada elastic chain dan NiTi closed coil spring. Hasil penelitian ini sejalan dengan penelitian yang dilakukan oleh Sulaiman dkk (2016) menemukan bahwa adanya penurunan gaya regang pada elastic chain antar kelompok perlakuan suhu. Hasil penelitian ini juga sesuai dengan penelitian yang 
dilakukan oleh Espinar-Escalona dkk (2013) menemukan bahwa terjadi penurunan force pada NiTi closed coil spring sebanyak 30\% pada temperatur $37^{\circ} \mathrm{C}$. Namun, perubahan temperatur tidak merubah sifat keelastikan dari NiTi closed coil spring. Adanya pengaruh suhu pada kekuatan elastis, Stevenson dkk melaporkan bahwa peningkatan suhu lingkungan secara signifikan mempengaruhi terhadap mekanisme degradasi yang bertanggung jawab atas kerusakan sifat mekanik elastomer poliuretan ${ }^{5}$ Paige dkk (2008) mengevaluasi tentang pengaruh siklus suhu pada kehilangan kekuatan elastik. Para penulis melaporkan bahwa cairan panas dapat mengurangi kekuatan diantara suhu panas dalam periode waktu yang singkat.

\section{SIMPULAN}

Hasil penelitian mengenai perubahan force NiTi closed coil spring dan elastic chain sebelum dan sesudah diaplikasikan terhadap perubahan temperatur, mengambil beberapa kesimpulan:

1. Terdapat perubahan force NiTi closed coil spring dan elastic chain terhadap temperatur pada saliva buatan.

2. Rata-rata force elastic chain dalam waktu 0 jam, 24 jam, 72 jam, 168 jam dan 240 jam adalah 80,$50 ; 62,36 ; 36,08 ; 29,39$; dan 19,17. Sedangan rata-rata force NiTi closed coil spring dalam waktu 0 jam, 24 jam, 72 jam, 168 jam dan 240 jam adalah 70,00; 60,61; 46,00; 39,89; dan 11,00.
3. Perubahan force pada elastic chain lebih kecil dibandingkan dengan perubahan force pada NiTi closed coil spring.

4. Elastic chain mempunyai elastisitas yang lebih baik untuk kembali ke bentuk semula dibandingkan dengan NiTi closed coil spring setelah diberi temperatur yang berbeda-beda.

\section{DAFTAR PUSTAKA}

1. Raharjo, P. Ortodonti dasar edisi 2. AUP; 2012. Hal: 2.

2. Salzman, J. A. Etiology of malocclusion and dentofacial deformities.In: practice of orthodontics. Philadephia and Montreal: JBLippicott Company (2000); p. 114-123, 378-386

3. Williams JK, Cook PK, Isaacson KG, Thom AR. Alat-Alat Ortodonsi Cekat : Prinsip dan Praktek. Alih bahasa oleh drg. Budi Susetyo. Jakarta: EGC. 2000.

4. Yodthong, N., Charoemratrote, C., Leethanakul, C. (2013). Factors Related to Alveolar Bone Thickness During Upper Incisor Retraction. Angle Orthod, Vol. 83, pp. 394-401.

5. Braga, E., G. Souza, P. Barretto, C. Ferraz, and M. Pithon. 2019. Experimental evaluation of strength degradation of orthodontic chain elastics immersed in hot beverages. Journal of Indian Orthodontic Society, 53(4), 244-248.

6. Melinda, N., Eddy, H. 2017. The impact of mouth-rinsing using chlorhexidine gluconate $0.2 \%$ to the amount of plaque-causing bacteria colonies in fixed orthodontic users. Journal of Dentomaxillofacial Science, 2(2), 91-94

7. Espinar-Escalona, E., J.M. LIamas-Carreras, J.M, Barrera-Mora, C. Abalos-Lasbrucci, dan F.J. Gil-Mur. 2013. Effect of temperature on the orthodontic clinical applications of niti closed-coil springs. Med Oral Patol Oral Cir Bucal. Available from http://dx.doi.org/doi:10.4317/medoral.19073

8. Krittika, C., Peerapong, S., Paisal, C. 2015. Effect of short-term temperature change on force exerted by super-elastic ni-ti alloy orthodontic closed coil spring. Journal of Mahidol University, 19,19-21. 
9. Hubert, K., Barbara, B. 2017. The mechanical strength of orthodontic elastomeric memory chains and plastic chains:an in vitro study.journal of medical of medical sciences Poland,26(3):373-378.

10. Haixia, G., Hongli, S., John, W. 2019. The effect of orthodontic clinical use on the mechanical characteristics of nickel-titanium closed-coil springs. Journal of Internasional Medical Research, 47(2), 803-814.

11. Peniasi, W. Diana, F.K.D. Kurniawan. 2018. Efek perendaman minuman probiotik terhadap daya lenting kawat ortodontik lepasan stainless steel. Dentin Jurnal Kedokteran Gigi, 2(1).

12. Alexandre, L.P., G. Oliveira, D. Dressano, L.R. Paranhos, and M.A. Scanavini. 2008. Avaliação das propriedades mecânicas dos elásticos e cadeias elastoméricas em ortodontia [An evaluation of the mechanical properties of elastic ligatures and power chains in orthodontics]. Revista Odonto, 16, 53-63.

13. Araujo, F.B,C., and W.J.S. Ursi. 2006. Estudo da degradação da força gerada por elásticos ortodônticos sintéticos [Study of force degradation produced by synthetic orthodontic elastics.]. R Dental Press Ortodon Ortop Facial, 11(6), 52-61.

14. Sulaiman, T.H., Y.K. Eriwati, dan D.J. Iriani. 2016. Pengaruh suhu terhadap penurunan gaya regang power chain ortodontik dalam larutan saliva buatan. Available online at http://www.lib.ui.ac.id/naskahringkas/201611//S Taufik\%20Hamzah\%20Sulaiman 